\title{
Utility of Big Area Additive Manufacturing for Part Production for Low-Head Hydropower
}

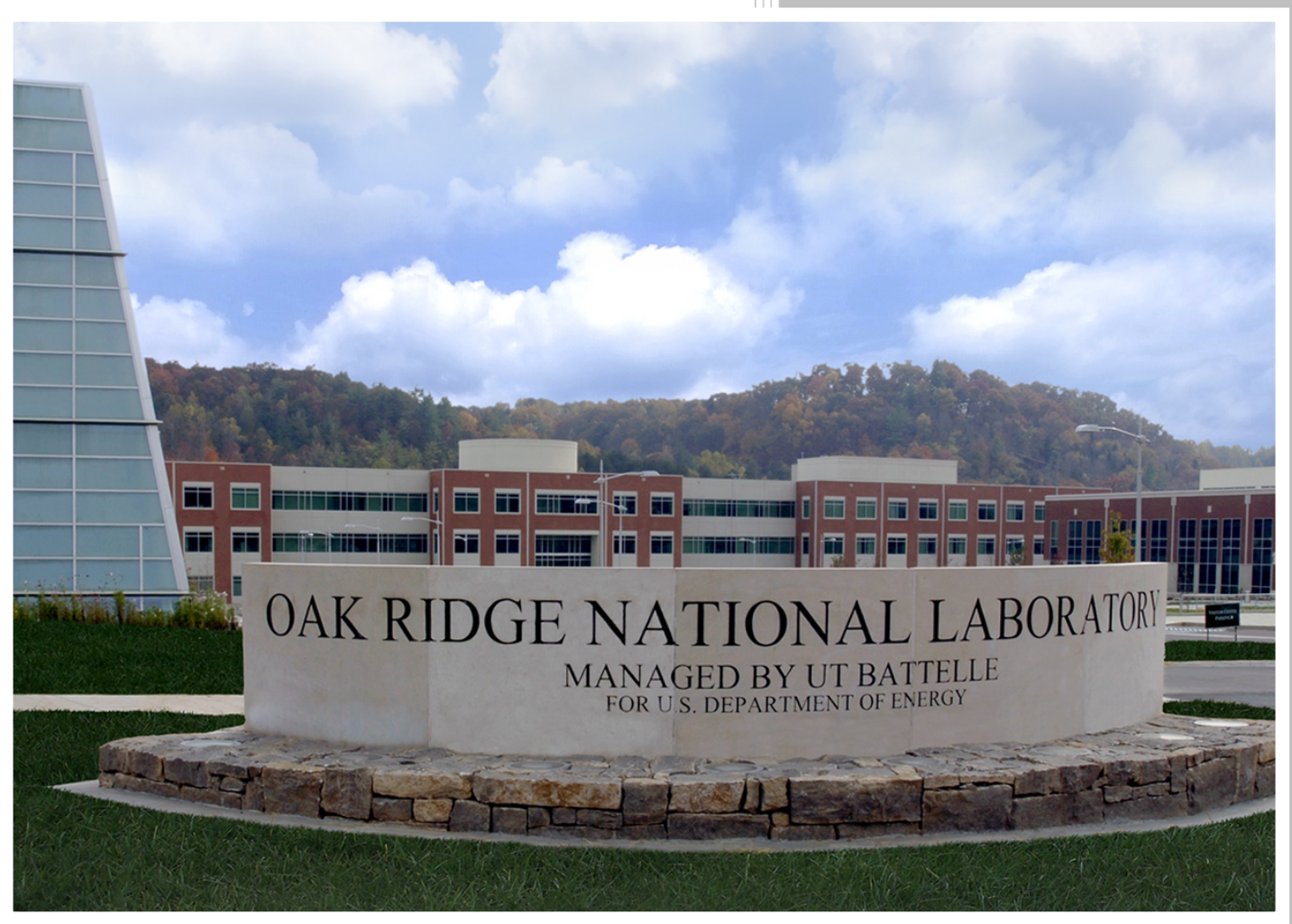

CRADA FINAL REPORT

NFE-18-07280
Brian Post

Alex Roschli Jesse Heineman Phillip Chesser John Lindahl

November, 2019 


\section{DOCUMENT AVAILABILITY}

Reports produced after January 1, 1996, are generally available free via US Department of Energy (DOE) SciTech Connect.

Website http://www.osti.gov/scitech/

Reports produced before January 1, 1996, may be purchased by members of the public from the following source:

National Technical Information Service

5285 Port Royal Road

Springfield, VA 22161

Telephone 703-605-6000 (1-800-553-6847)

TDD 703-487-4639

Fax 703-605-6900

E-mail info@ntis.gov

Website http://www.ntis.gov/help/ordermethods.aspx

Reports are available to DOE employees, DOE contractors, Energy Technology Data Exchange representatives, and International Nuclear Information System representatives from the following source:

Office of Scientific and Technical Information

PO Box 62

Oak Ridge, TN 37831

Telephone 865-576-8401

Fax 865-576-5728

E-mail reports@osti.gov

Website http://www.osti.gov/contact.html

This report was prepared as an account of work sponsored by an agency of the United States Government. Neither the United States Government nor any agency thereof, nor any of their employees, makes any warranty, express or implied, or assumes any legal liability or responsibility for the accuracy, completeness, or usefulness of any information, apparatus, product, or process disclosed, or represents that its use would not infringe privately owned rights. Reference herein to any specific commercial product, process, or service by trade name, trademark, manufacturer, or otherwise, does not necessarily constitute or imply its endorsement, recommendation, or favoring by the United States Government or any agency thereof. The views and opinions of authors expressed herein do not necessarily state or reflect those of the United States Government or any agency thereof. 
Energy and Transportation Science Division

Advanced Manufacturing Office

\title{
Utility of Big Area Additive Manufacturing for Part Production for Low-Head Hydropower
}

\author{
Authors \\ Brian Post \\ Alex Roschli \\ Jesse Heineman \\ Phillip Chesser \\ John Lindahl \\ Vito Gervasi \\ Randal Mueller
}

Date Published:

November 2019

\author{
Prepared by \\ OAK RIDGE NATIONAL LABORATORY \\ Oak Ridge, Tennessee 37831-6283 \\ managed by \\ UT-BATTELLE, LLC \\ for the \\ US DEPARTMENT OF ENERGY \\ under contract DE-AC05-00OR22725
}

Approved For Public Release 



\section{CONTENTS}

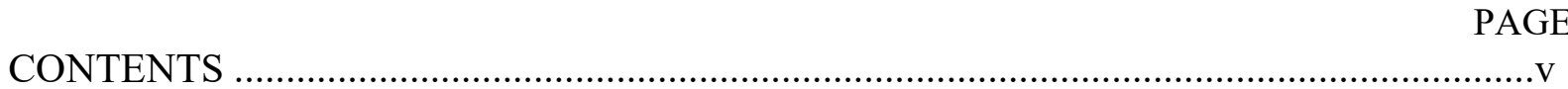

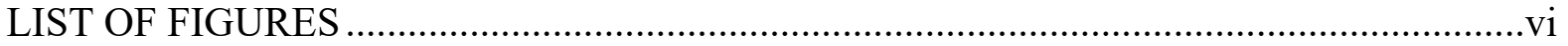

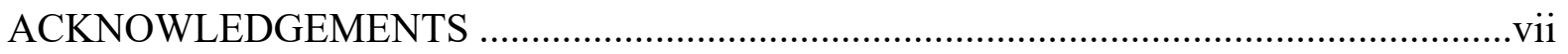

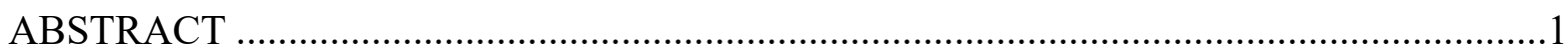

1. Utiility of Big Area Additive manufacturing for part production of low-head hydropower 1

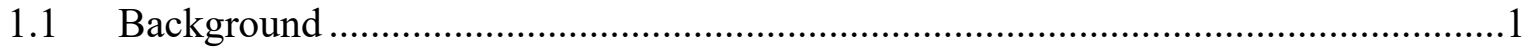

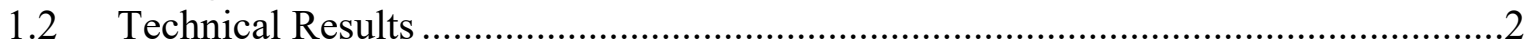

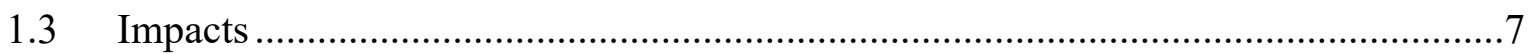

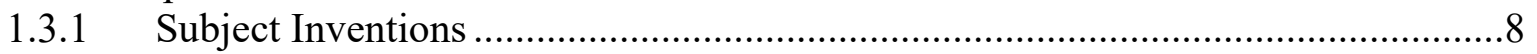

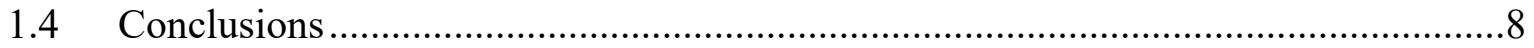

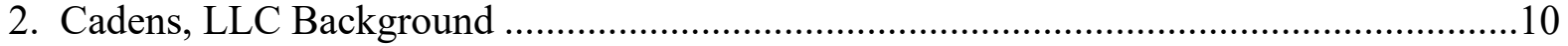




\section{LIST OF FIGURES}

Fig. 1. Lower draft tube original CAD model.

Fig. 2. The CAD model of one half of the draft tube with the external structures (left). The external support structures are shown in green (right).

Fig. 3. The CAD model of the hydropower assembly. The draft tube with external support structures is located on far left of the image.

Fig. 4. The first half of the draft tube as printed. It is flipped upside down, so the support structures are seen on top .3

Fig. 5. The second half of the draft tube as printed. ........................................................4

Fig. 6. The CAD model of the thimble (left) and the final printed version (right)..................4

Fig. 7. The CAD model of the runner housing layup mold (left) and the final printed version

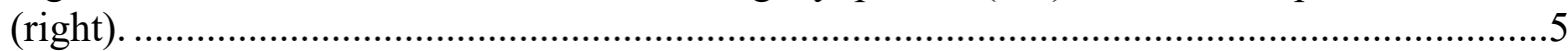

Fig. 8. CAD models to show the runner and stator as they fit into the housing.......................5

Fig. 9. Runner spacer plates printed by Cadens.............................................................6

Fig. 10. The thimble after post processing and prep work by Cadens................................. 7 


\section{ACKNOWLEDGEMENTS}

This CRADA NFE-18-07280 was conducted as a Technical Collaboration project within the Oak Ridge National Laboratory (ORNL) Manufacturing Demonstration Facility (MDF) sponsored by the US Department of Energy Advanced Manufacturing Office (CPS Agreement Number 24761).

Opportunities for MDF technical collaborations are listed in the announcement "Manufacturing Demonstration Facility Technology Collaborations for US Manufacturers in Advanced Manufacturing and Materials Technologies" posted at http:/web.ornl.gov/sci/manufacturing/docs/FBO-ORNL-MDF-2013-2.pdf. The goal of technical collaborations is to engage industry partners to participate in short-term, collaborative projects within the Manufacturing Demonstration Facility (MDF) to assess applicability and of new energy efficient manufacturing technologies. Research sponsored by the U.S. Department of Energy, Office of Energy Efficiency and Renewable Energy, Advanced Manufacturing Office, under contract DE-AC0500OR22725 with UT-Battelle, LLC.

Cadens would like to acknowledge Adam Witt, Miles Mobley, Rebecca Brink and Kevin Stewart of ORNL Water Power group for their contributions on the AM draft tube.

The ORNL MDF would like to acknowledge Katherine Gaul and Abigail Barnes for their contributions to the preparation of this technical report. 


\begin{abstract}
ORNL worked with Cadens, LLC, to explore the use of additive manufacturing (AM) to produce low-cost parts for low-head hydropower systems. Cadens develops design optimization software that leverages the flexible, low-cost, high-strength benefits of AM and composite materials. Cadens also operates a micro-hydro lab to test AM components in controlled environments. Until now, Cadens' tests have been limited to components of a size that they can cost-effectively manufacture using local commercial systems. This project provided an opportunity for Cadens to scale up their modular AM hydropower parts using the capabilities of Big Area Additive Manufacturing (BAAM). This project was a success and resulted in the design and fabrication of several end-use parts of a hydropower system, using a Big Area Additive Manufacturing (BAAM) system. The fabricated parts include a draft tube, thimble, runner housing mold, PVC end fitting and two PVC pipe supports. In addition, a runner system was fabricated using fused deposition modeling on a 3D Platform Workbench 400 Series System.
\end{abstract}

\title{
1. UTIILITY OF BIG AREA ADDITIVE MANUFACTURING FOR PART PRODUCTION OF LOW-HEAD HYDROPOWER
}

This phase 1 technical collaboration project (MDF-TC-2018-144) began on July 19, 2018 and was completed on November 2019. The collaboration partner, Cadens, LLC, is a small business. The results of this project include the successful fabrication and testing of several ducting elements, using additive manufacturing.

\subsection{BACKGROUND}

Cadens' intended products are AM micro-to-small hydropower S-turbine systems, with an intake, guide vanes, turbine runner, shaft, curved conveyance including intake and diffuser, as well as an offthe-shelf generator situated out of the flow path for simplicity in maintenance, assembly, and installation. The system is modular in that several sub-components are manufactured and then assembled to make the final integrated machine: a powertrain plus conveyance (PPC) system.

Cadens' target market is small, low-head hydropower plants. There are currently over 1,700 small hydropower plants in the country providing low-carbon, reliable electricity. A resource assessment conducted by ORNL indicated the presence of an additional $29 \mathrm{GW}$ of new, small hydropower technical potential across 10,000 sites (Kao et al., 2014). However, the Department of Energy modeled the deployment of this potential and predicted $0 \mathrm{GW}$ will be developed by 2050 , unless the industry can radically reduce costs. DOE suggested exploring the use of new materials and manufacturing methods as one cost reduction pathway (DOE, 2016). ORNL has also suggested using standardization and modularity as strategies to make small low-head hydropower development affordable (Witt et al., 2017). Cadens' modular design, coupled with their optimization software and AM components, enables a first-of-its-kind validation of small modular hydropower systems. By producing semi-custom modular systems that can deploy with high efficiency across many different sites with few changes to design and manufacturing processes, Cadens believes the system can be a low-cost, high efficiency solution for the hydropower industry.

What is not well understood is the durability and overall performance of an integrated PPC system, made with BAAM methods/materials and operated continuously under normal and off-design conditions in a field demonstration. Thus, the PPC project test plan involves evaluating the durability 
of an AM PPC by measuring the wear to components under continuous operation as well as the overall performance in both off-design and normal operating conditions. The DOE MDF at ORNL is uniquely positioned to assist Cadens because of its ability to rapidly push the envelope in large-scale AM.

\subsection{TECHNICAL RESULTS}

This project began with the design of the first part that was to be fabricated using the BAAM system. This part is called the lower draft tube. Cadens provided the computer-aided designed (CAD) model, and then ORNL and Cadens worked together to improve the design and make it printable. Fig. 1 shows the original CAD model of the lower draft tube.

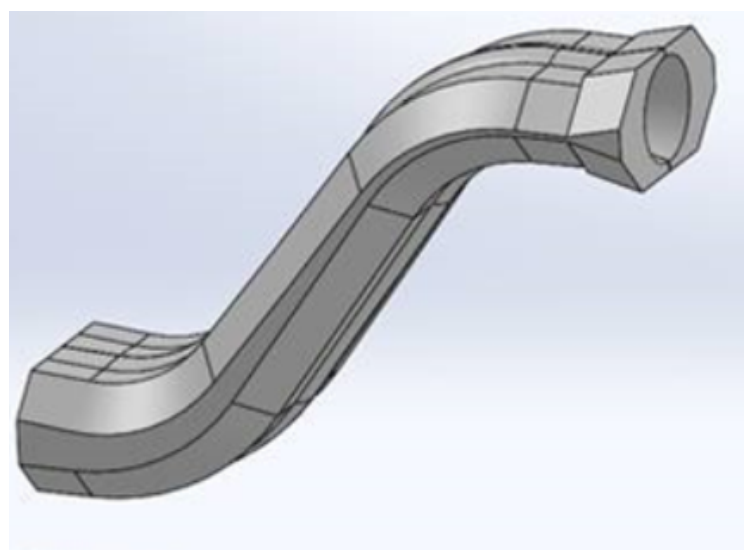

Fig. 1. Lower draft tube original CAD model.

Due to an inherent AM limitation of not being able to deposit material if there is nothing below to support it, a tube is not printable without support material. Therefore, the draft tube was divided into two halves. Each half was printed separately and later assembled. The geometry of the draft tube also required the addition of external support structures that run the length of the tube (Fig. 2).
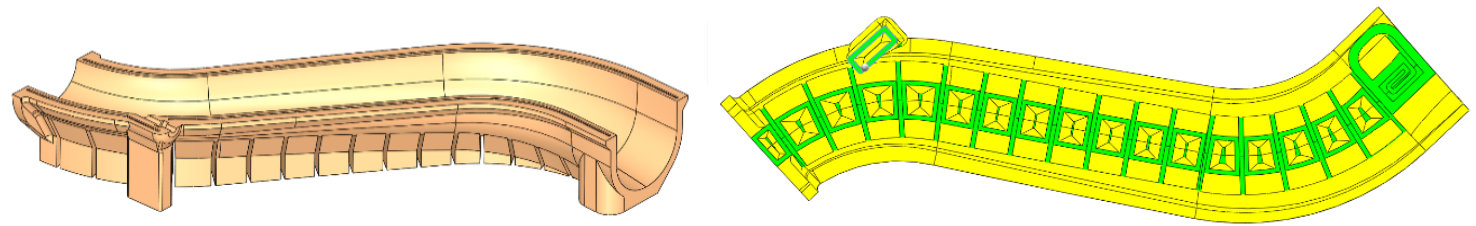

Fig. 2. The CAD model of one half of the draft tube with the external structures (left). The external support structures are shown in green (right).

Although the external support structures were not originally intended to be on the draft tube, the structures were helpful for moving the large tube and did not interfere with the performance of the tube. Therefore, they were incorporated into the final hydropower assembly's CAD drawings (Fig. 3). 


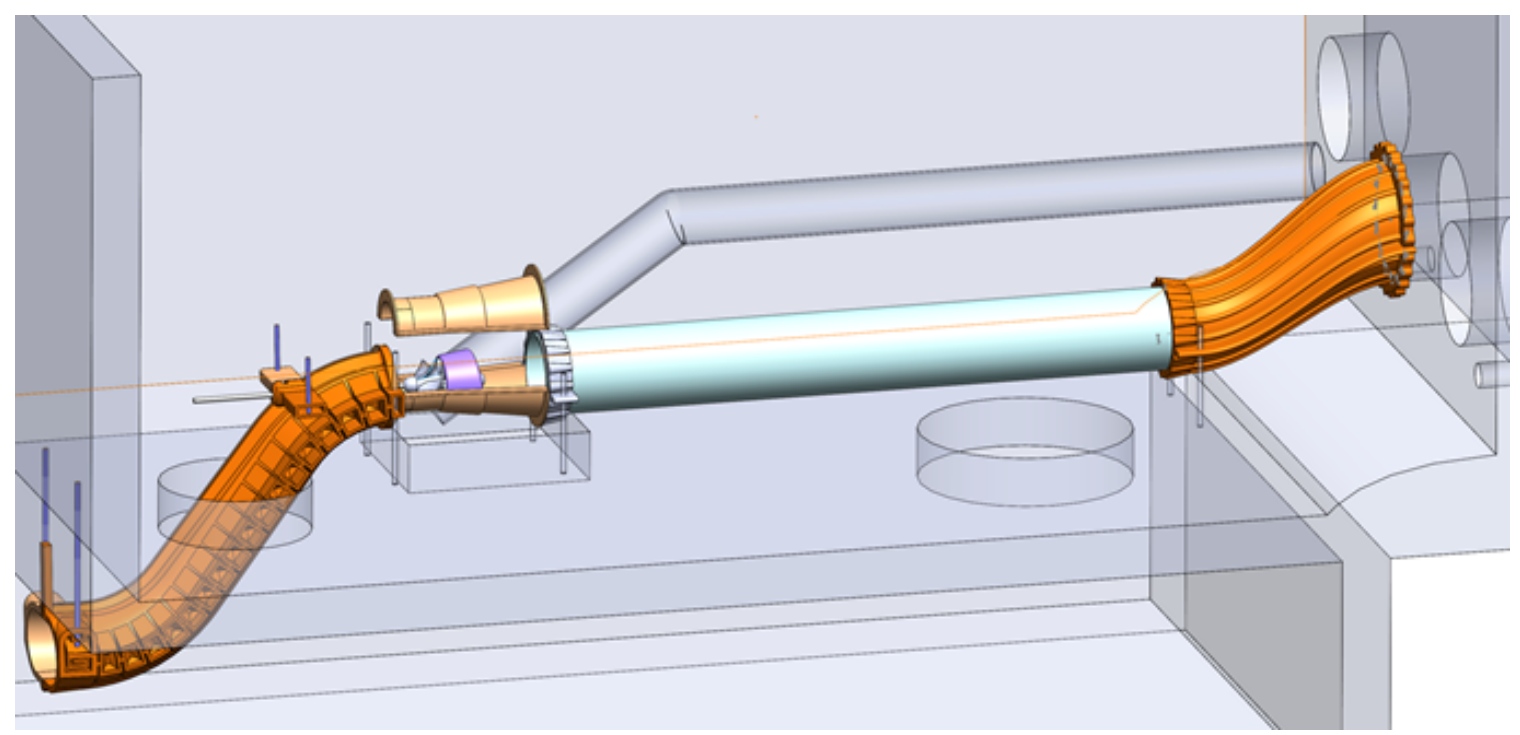

Fig. 3. The CAD model of the hydropower assembly. The draft tube with external support structures is located on far left of the image.

Each half of the final printed draft tube is shown in Figs. 4 and 5. The prints each took approximately 9 hours and 20 minutes. The material used to fabricate the tubes was $20 \%$ carbon fiber-reinforced acrylonitrile butadiene styrene (ABS). Each half weighed approximately 344 pounds, for a total of 688 pounds.

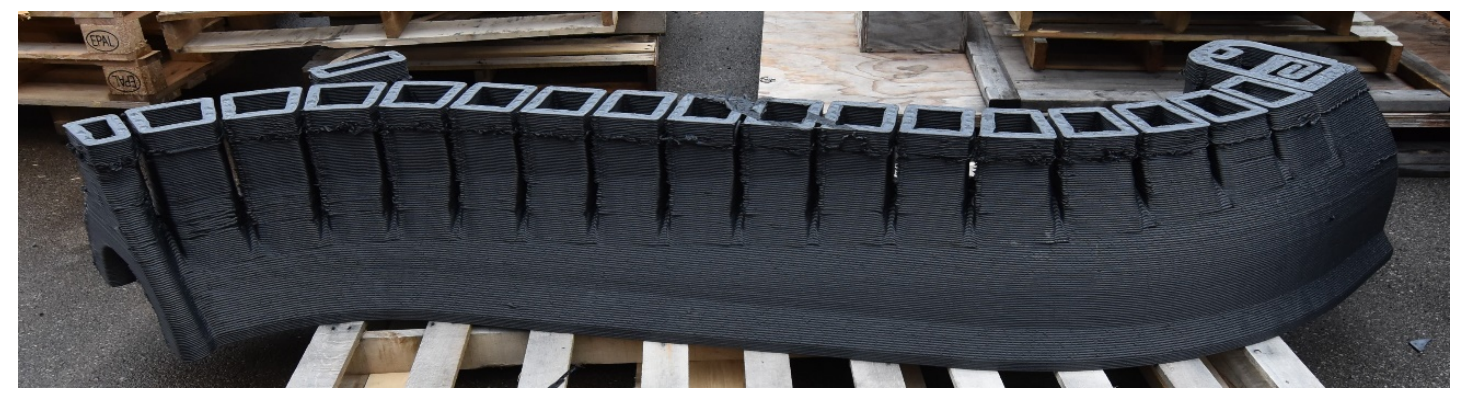

Fig. 4. The first half of the draft tube as printed. It is flipped upside down, so the support structures are seen on top. 

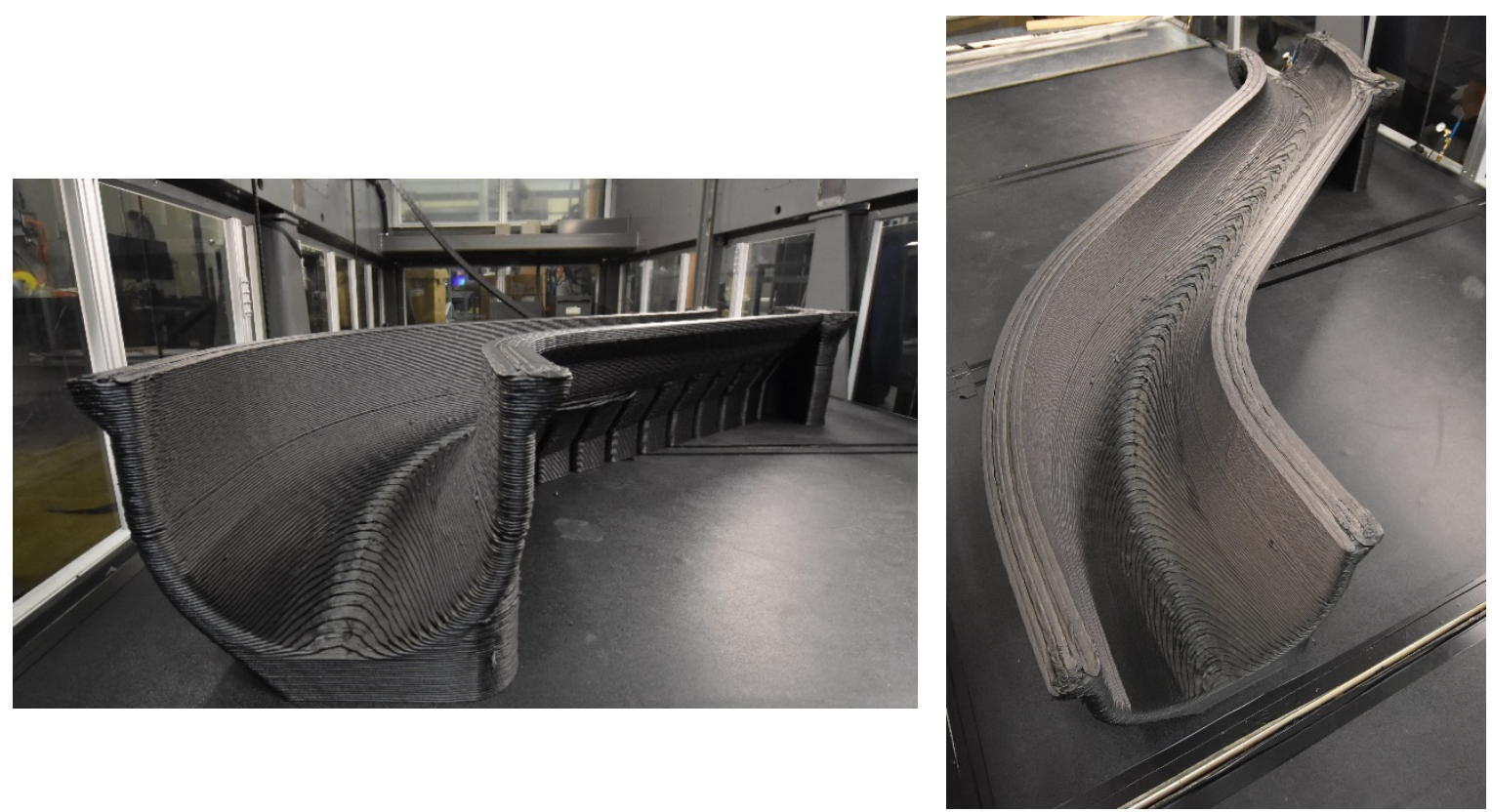

Fig. 5. The second half of the draft tube, as printed.

The second aspect of the hydropower system, the thimble, also went through design iterations between ORNL and Cadens and was printed using the BAAM system. The CAD model of the piece and the final as-printed part are shown in Fig. 6 . The long thru-channels house $1 / 8^{\text {th }}-3 / 16^{\text {th }}$ rods that hold the stack in compression during use.
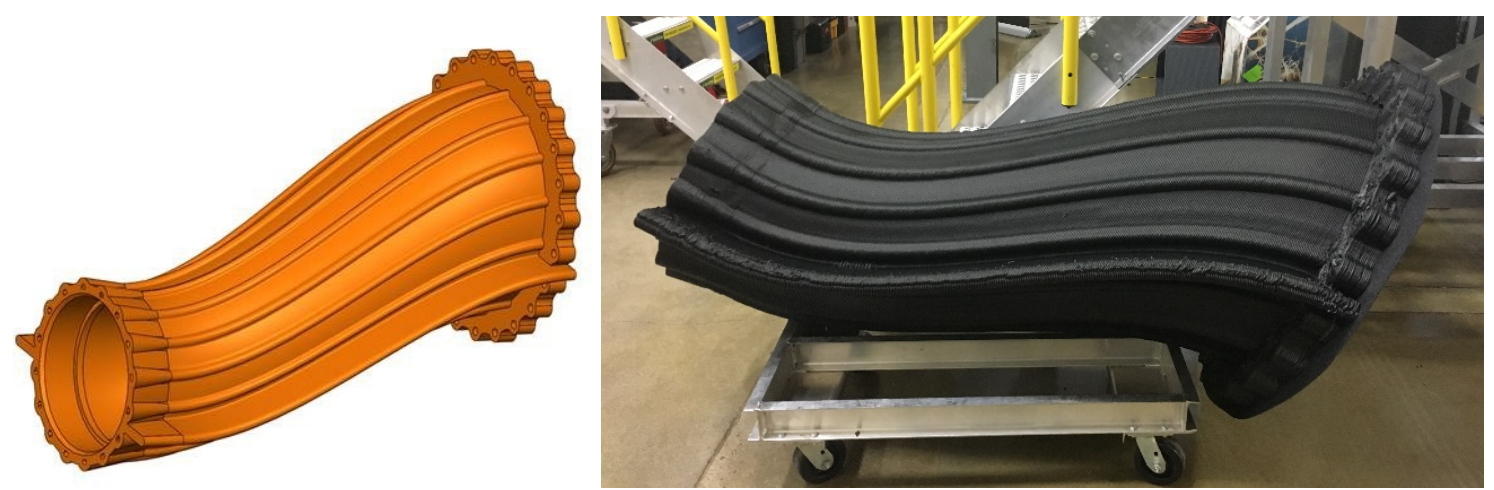

Fig. 6. The CAD model of the thimble (left) and the final printed version (right).

The final piece to be printed using BAAM was a layup mold for the runner housing. It was printed with BAAM, spray coated to fill any voids and even out the surface, CNC machined to get the exact tolerances, and then spray-coat sealed to protect the surface. The print took approximately six hours and weighed $81 \mathrm{lbs}$. 

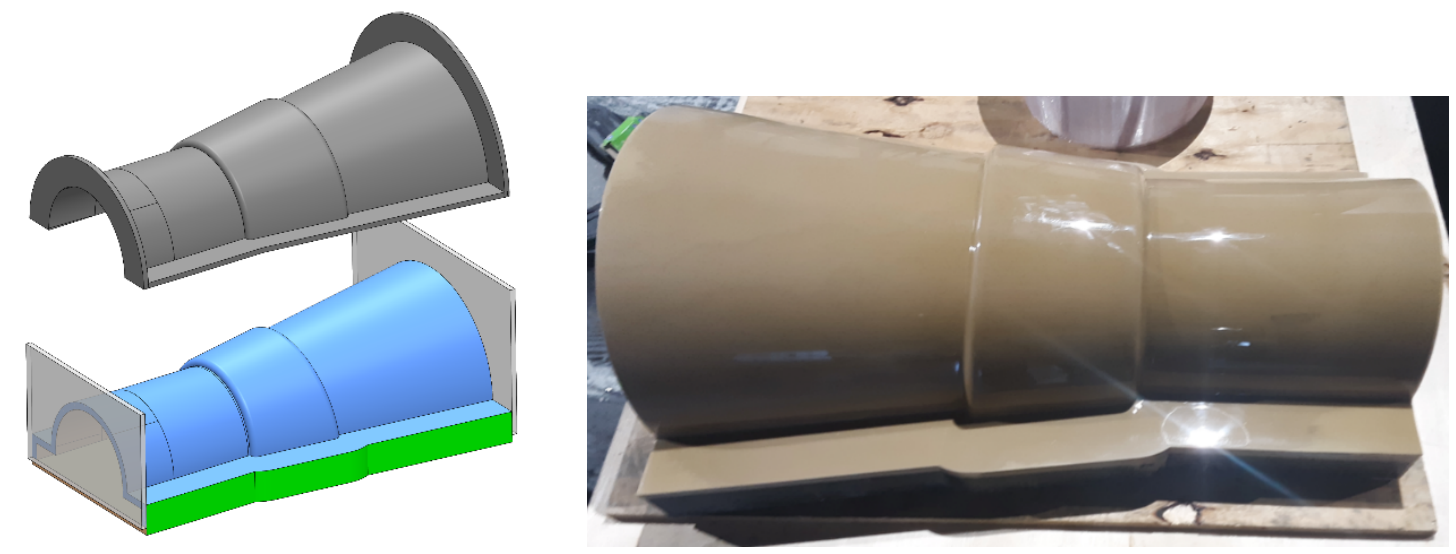

Fig. 7. The CAD model of the runner housing layup mold (left) and the final printed version (right).

Following the large prints on BAAM, there were smaller parts that needed to be printed - the runner and stator. These were both printed at ORNL on the 3D Platform Workbench 400 Series printer using Polyethylene terephthalate (PETG). Cadens provided the spacer plates needed for final assembly.
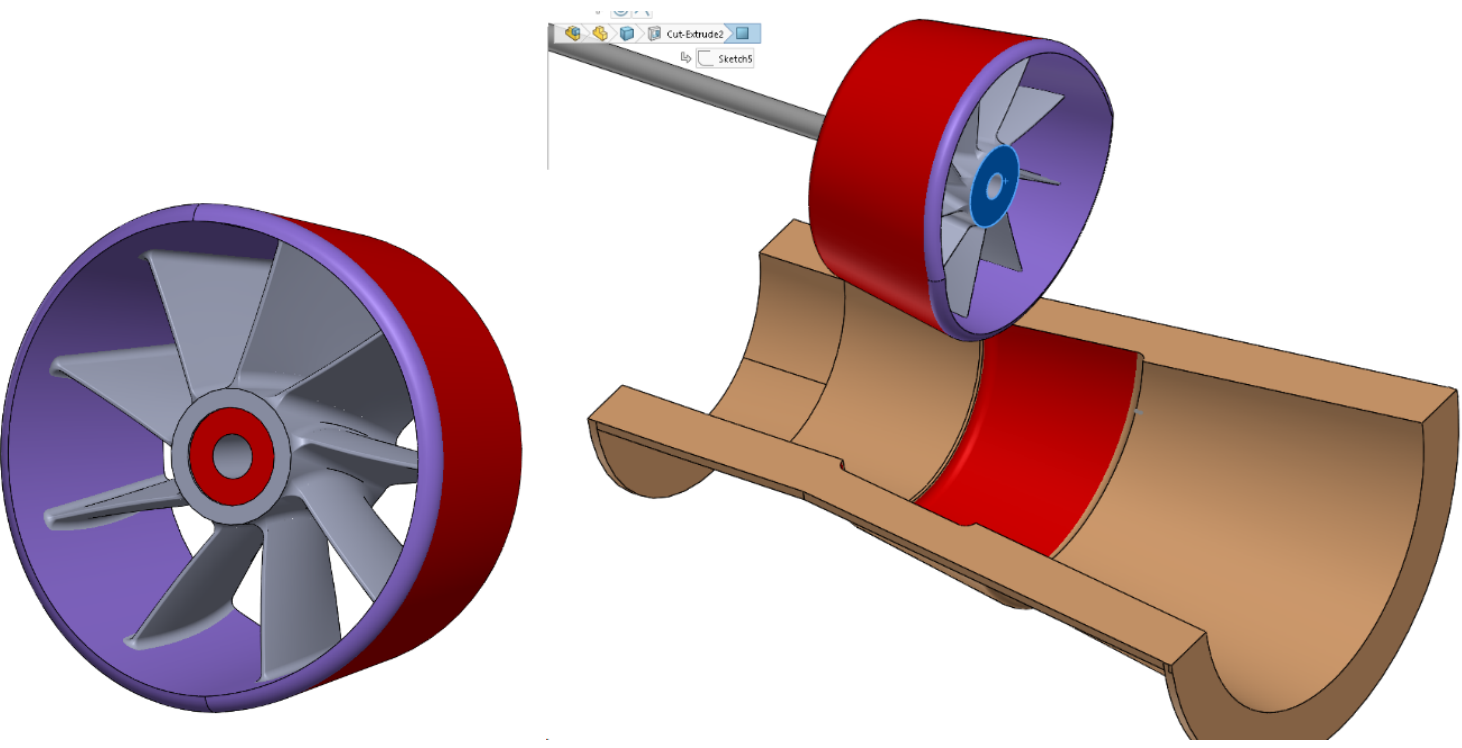

Fig. 8. CAD models to show the runner and stator as they fit into the housing. 


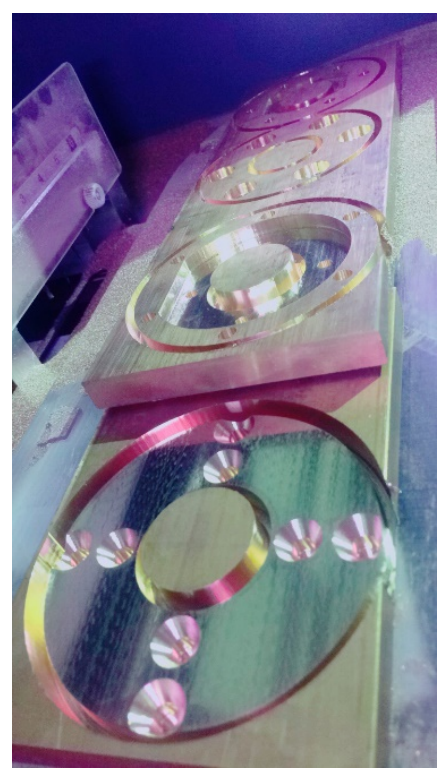

Fig. 9. Runner spacer plates provided by Cadens

With all the parts printed, ORNL shipped them to Cadens for preparation, assembly, and testing. The draft tube required minor repairs and sanding to perfect the fit. The thimble needed to be drilled out to thread the rods through; it also required sanding and epoxying to fit the PVC pipe into it.

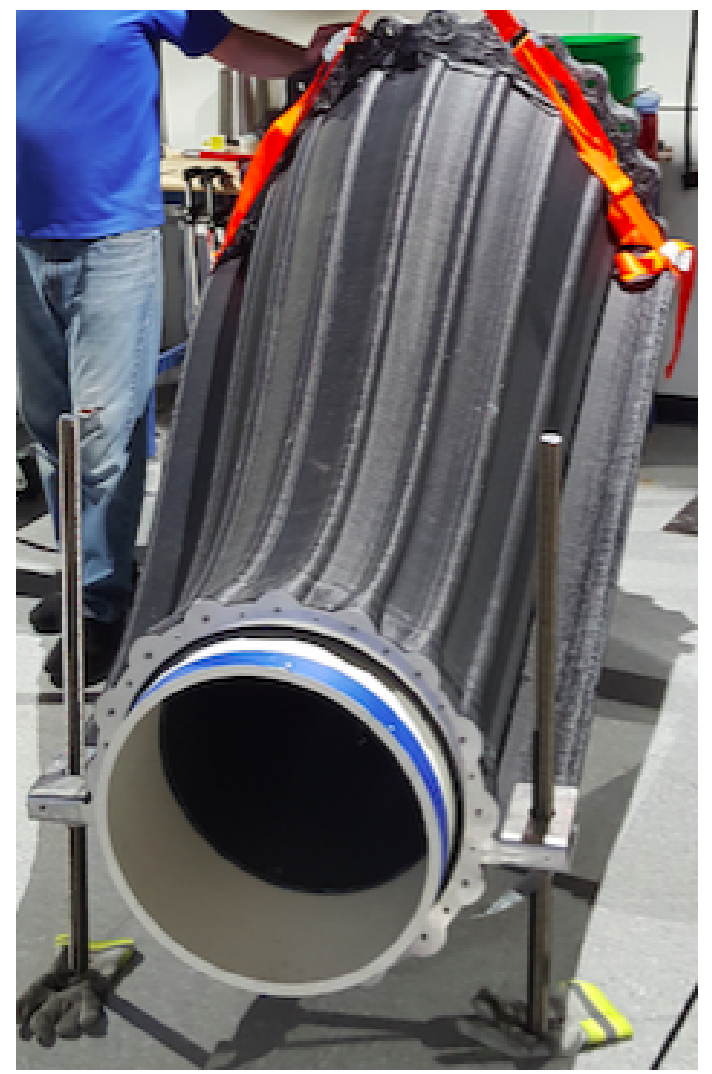

Fig. 10. The thimble after post processing and prep work by Cadens. 


\subsection{IMPACTS}

This project had an impact in several areas of hydropower technology development. They include decreasing costs, entering a new market, and reducing process energy use.

The volume of components needed for the hydropower industry is low, so part production costs are generally high. Site conditions also vary from location to location, which results in custom, sitespecific designs. This project report provides other companies, and the public, access to information describing the print process, assembly, and commercial coating/sealing techniques for finishing enduse parts. This information can provide a path forward for cost reduction in the manufacturing of small batch hydropower systems.

The small hydropower market is stagnant - over the past fifteen years, only seven small hydropower plants with 24.4 MW of total capacity (mostly in Alaska) have received a FERC license to operate (Witt et al., 2017). This project helped to revitalize the market for small hydro by demonstrating low-cost, reliable production enabled by rapid design and manufacturing.

The conventional approach to this project would be to use a metal turbine runner and concrete or steel pipes that are overdesigned for low-pressure systems. Using AM, which combines low cost feedstock with quick manufacturing times, significantly reduced the energy used in the manufacturing process. The resulting Micro Hydro Test-bed allows for further advancement in the state-of-the-art of the runner and turbine, as well as energy conversion methods and system/software/model optimization. This test-bed is the first of its kind and supports the industry interest in testing many system components, materials, and energy conversion/storage regimes.

\subsubsection{SUBJECT INVENTIONS}

No subject inventions resulted from this project.

\subsection{CONCLUSIONS}

Through this project, ORNL and Cadens have demonstrated how 3D printing can be used to help the hydropower industry. Several parts were able to be made on BAAM both quickly and inexpensively, and parts with finer details were made using a 3D Platform System. Final assembly for testing the printed parts is under way, and phase 2 will explore printing and developing many additional components, as well as thorough testing of all the designs. 


\section{CADENS, LLC BACKGROUND}

Cadens is a clean energy startup located in Sullivan, WI advancing environmentally compatible, low-cost hydropower specifically with additive manufacturing. Cadens plans to lead the way in the development of new hydropower technologies. They are building a team to actively address conversions to produce clean, renewable energy at existing non-power dams and existing powered dams in need of maintenance and upgrades. With an agile combination of off-the-shelf and standardized parts, along with site-specific turbines generated on 3D printers, they envision modular, drop-in hydropower systems that are lightweight, energy dense, and optimized for each specific site. A particular focus are dams with a capacity of $<1 \mathrm{MW}$, which represent $98 \%$ of the 54,000 suitable NPD's. River communities, private landowners, and businesses that must rebuild vital dam infrastructure can partner with Cadens to retrofit non-hydropower dams with new, lightweight hydro turbine machines. 